\title{
NEW AND SUPPLEMENTARY RECORDS OF MARINE ISOPODA FOR THE NETHERLANDS AND THE SOUTHERN NORTH SEA SINCE 1956, WITH A NOTE ON PELTOGASTER PAGURI (CRUSTACEA, CIR- RIPEDIA)
}

BY

\author{
J. P. H. M. ADEMA \\ and \\ P. H. M. HUWAE \\ Rijksmuseum van Natuurlijke Historie, Leiden \\ With 8 text-figures, 6 tables and 5 maps
}

\section{INTRODUCTION}

Part XVI of the Fauna van Nederland, Isopoda \& Tanaidacea (Holthuis, 1956), deals with 27 species of Isopoda occurring in salt and/or brackish water. According to Holthuis (1956) the occurrence in the Netherlands of two of these, Sphaeroma serratum (Fabricius, 1787) and Bopyrus squillarum Latreille, 1802, is very doubtful and will remain so, as the material on which the records were based is lost and no new records of these species have been published for the Netherlands.

Since 1956 many new data were obtained for several of the remaining 25 species, while 12 species were found for the first time in Dutch waters or in the southern North Sea. The present paper deals with the more interesting finds. Part of the species mentioned here have been discussed earlier. A key for the Dutch species is given by Huwae (1977). Since the publication of the key, three species, Pseudione hyndmanni (Bate \& Westwood, 1868), Ione thoracica (Montagu, 1808) and Astacilla longicomis (Sowerby, 1806), were added to the Dutch fauna list. Two species, Arcturella dilatata (G. O. Sars, 1882) and Liriopsis pygmaea (Rathke, 1843) have been included here, because so far they were not represented in the collection of the Rijksmuseum van Natuurlijke Historie, although, properly speaking, they were not collected in the "Dutch" part of the southern North Sea.

Most of the records from the Dutch coast are based on material obtained by members of the "Strandwerkgemeenschap van de Koninklijke Nederlandse Natuurhistorische Vereniging, de Nederlandse Jeugdbond voor Natuurstudie en de Algemeen Christelijke Jeugdbond voor Natuurstudie en Natuurbescherming" (the Shore Study-group of the Royal Netherlands Natural History Society, the Netherlands and General Christian Junior Leagues for Nature Study); these records are filed in the Central Register (CS) of this Study-group and kept in the Rijksmuseum van Natuurlijke Historie, Leiden.

The data concerning material from the southern North Sea are mainly based on the collections made during the 1972-1981 cruises with the research vessel 
"Aurelia" of the Nederlands Instituut voor Onderzoek der Zee (NIOZ) (Creutzberg, 1979). They were compiled by the senior author during a stay at the NIOZ in january 1980. A lesser part of the records are based on a collection made by the Rijksinstituut voor Visserij Onderzoek, IJmuiden (RIVO) and were compiled by the junior author.

Data on the distribution of Cyathura carinata (Krøyer, 1848) in the Delta area were received from the Delta Instituut voor Hydrobiologisch Onderzoek, Yerseke. The whole was completed with data derived from literature and own observations.

The sequence of the species dealt with is based on the systematical classification as given by Huwae (1977).

\section{Family Anthuridae Leach, 1814 \\ Cyathura carinata (Krøyer, 1848)}

(table 1; map 1)

Cyathura carinata; Schuurmans Stekhoven \& De Marees van Swinderen, 1936: 120. De Vos, 1939: 5; 1941: 46. Schuurmans Stekhoven, 1944: 26. Holthuis, 1954: 205; 1956: 38, fig. 9. Den Hartog, 1961: 414, fig. 3. Burbanck \& Burbanck, 1964: 865, figs. 1-6. Wolff, 1973: 151. Huwae, 1977: 14, figs. 19, B 17

Cyathura carinata (Krøyer) is a brackish water species. In the Delta area (the estuarium of the rivers Rijn, Maas and Schelde) it is found in waters with a salinity of $3-15 \% \mathrm{Cl}^{-}$, with an optimum at 3-10\%. Experiments proved that it can survive in water with a salinity of 4.5-19.5\% $\mathrm{Cl}^{-}$(Wolff, 1973). The species seems to prefer mud, but occurs on sandy substrates as well (Holthuis, 1956).

In the former Zuiderzee (now called IJsselmeer) the species was abundant, especially in the years following the closure (1932), when the water had a salinity of $0,5-2 \%$ (which is considerably lower that its optimum in the Delta area) (Schuurmans Stekhoven \& De Marees van Swinderen, 1936; De Vos, 1939, 1941; Schuurmans Stekhoven, 1944; Holthuis, 1954). A further decrease in salinity caused its extinction in the IJsselmeer around 1939 (Holthuis, 1954). $C$. carinata does not occur in the brackish inland waters of the Delta area (Wolff, 1973). According to Huwae (1977) the species has been found in brackish inland waters in the province of Noord-Holland. In the Delta area it is known from the Westerschelde, the Kanaal door Zuid-Beveland, the Krammer, the Volkerak, the Haringvliet and Grevelingen (map 1, after Den Hartog (1961), completed).

In the Haringuliet it has been found at several localities (Den Hartog, 1961; Burbanck \& Burbanck, 1964); probably it was common in the entire area. The last collected specimens were found on 22.iii.1965 near Stad aan het Haringvliet (leg. A. Sandee). After the closure in 1970 it probably became extinct in this area (Huwae, 1977). In the Krammer it was found for the last time on 31.xi.1970 and 5.viii.1971 near Drievriendenpolder (leg. Delta Instituut). Den Hartog (1961) and Wolff (1973) do not cite exact data and localities; the specimens of the collection of the Delta Instituut, however, were all collected between 1958 and 1971. 
TABLE 1

Distribution of Cyathura carinata in the Grevelingen

$\begin{array}{llcll}\text { Date } & \text { Locality } & \text { Number } & \text { Leg. } & \text { Col. } \\ 1979 & \text { Herkingen } & 1 & \text { R. Lambeck } & \text { De1ta Inst. } \\ 29 . v .1980 & \text { Herkingen } & 2 & \text { E. Alkema } & \text { De1ta Inst. } \\ \text { 4.vi. } 1980 & \text { Volkerak } & 1 & \text { J. Coosen } & \text { De1ta Inst. } \\ 25 . \text { iv. } 1980 & \text { Herkingen } & 1 & \text { E. Alkema } & \text { De1ta Inst. } \\ \text { 1.viii. } 1980 & \text { Battenoord } & 47 & \text { E. A1kema } & \text { De1ta Inst. } \\ 25 . i x .1980 & \text { Herkingen } & 1 & \text { E. Alkema } & \text { De1ta Inst. }\end{array}$

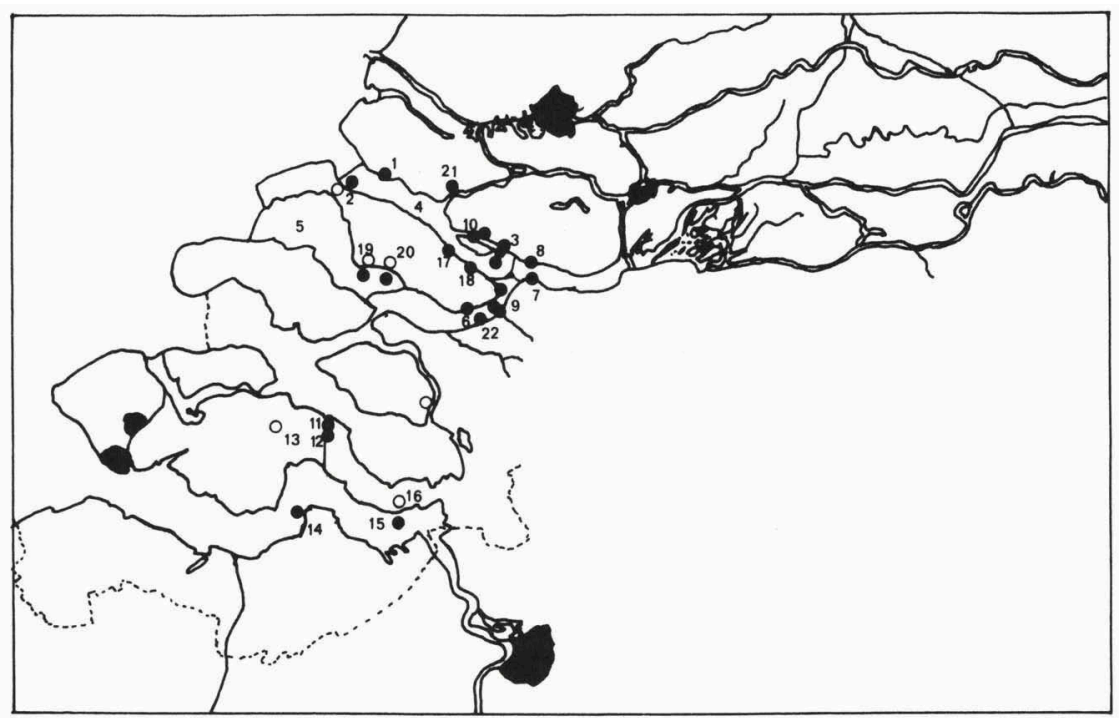

Map 1. Localities of Cyathura carinata in the Delta aerea. 1. Hellevoetsluis; 2. Stellendam; 3 . Hitsertse Kade; 4. Haringuliet; 5. Grevelingen; 6. Krammer and Volkerak; 7. Willemstad; 8. Numansdorp; 9. Dintelsas; 10. Vuile Gat; 11. Wemeldinge; 12. Postbrug; 13. Goes; 14. Ossenisse; 15. Westerschelde; 16. Bath; 17. Stad aan het Haringuliet; 18. Den Bommel; 19. Herkingen; 20. Battenoord; 21. Zuidland; 22. Drievriendenpolder.

From the years 1971-1979 no records are known to the authors. In 1979 and 1980 scientists of the Delta Instituut rediscovered the species in the Volkerak and in the closed Grevelingen near Herkingen and Battenoord (map 1, table 1). Before the closure of the Grevelingen in 1971 the species was not known from this area. In the summer of 1980 the Grevelingen had a salinity of $17 \% \mathrm{Cl}^{-}$; before the closure the salinity was too high for $C$. carinata. In the Grevelingen the species lives on a bottom of pure sand and in vegetations consisting mainly of Zostera marina, the common sea-grass. 
The collection of the Leiden Museum holds one specimen of Eurydice affinis Hansen (RMNH 3132), collected in 1947 on the beach at Haamstede (leg. W. Vervoort). This fact has been overlooked until 1966, when it was noticed by Wolff (1966); it appeared to be the first record of this species for the North Sea. Wolff (1973) gave ecological data of $E$. affinis, indicating that it prefers sandy beaches with sand of smaller grain size than that in which the more common $E$. pulchra Leach, 1815, is found. The latter is found frequently along the whole Dutch coast; $E$. affinis seems to be confined to the area south of Hoek van Holland, province of Zuid-Holland, where it is rather common (Wolff, 1973; Huwae, 1977).

\section{Eurydice spinigera Hansen, 1890}

Eurydice spinigera; Holthuis, 1950: 5. Wolff, 1966: 226, fig. 3c, d. Van der Baan \& Holthuis, 1969: 355, table 1. Huwae, 1977: 16, fig. B 28.

The fact that Eurydice spinigera Hansen had been reported several times from the southern North Sea, made it likely that it could also occur in the Netherlands (Wolff, 1966). Holthuis (1950) mentioned the occurrence of this species at the Belgian coast. Van der Baan \& Holthuis (1969) cited the first record of $E$. spinigera for Dutch waters. In the years 1955-1956 several specimens were collected near the lightship "Noord-Hinder", at $51^{\circ} 39^{\prime} \mathrm{N} 02^{\circ} 34^{\prime} \mathrm{E}$, and in the

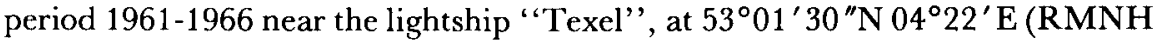
$167,1311,2056,3432-3448)$. The species has not yet been recorded from the Dutch coast itself (Huwae, 1977).

Cirolana borealis Lilljeborg, 1851

(fig. 1; map 2; table 2)

Cirolana borealis; Holthuis, 1950: 4. Gruner 1965: 39, figs. 27-31. Huwae, 1976: 65, fig. 3; 1977: 15, fig. B 23a, b.

Cirolana borealis Lilljeborg, not mentioned by Holthuis (1956), appeared to be fairly common north-west of the Dutch Wadden Islands; the species has been frequently found in stomachs of the whiting, Merlangius merlangius (Linnaeus, 1758), caught in that area (map 2). The collection of the Leiden Museum holds a specimen from the stomach of the skate, Raja batis Linnaeus, 1758, collected on 26.i. 1950 at $54^{\circ} 18^{\prime} \mathrm{N} 05^{\circ} 21^{\prime} \mathrm{E}$ (RMNH 3126) and a specimen collected towards the end of october 1954 in the Deep Hole, west of Den Helder, at $53^{\circ} 40^{\prime} \mathrm{N}$ $04^{\circ} 15^{\prime} \mathrm{E}$ (RMNH 1985, leg. P. Smit). Several more data on C. borealis from the southern North Sea were obtained from the NIOZ and RIVO (table 2).

Holthuis (1950) quoted one record from near the coast of England, off Harwich; according to Gruner (1965) C. borealis is known from the Belgian and Ger- 


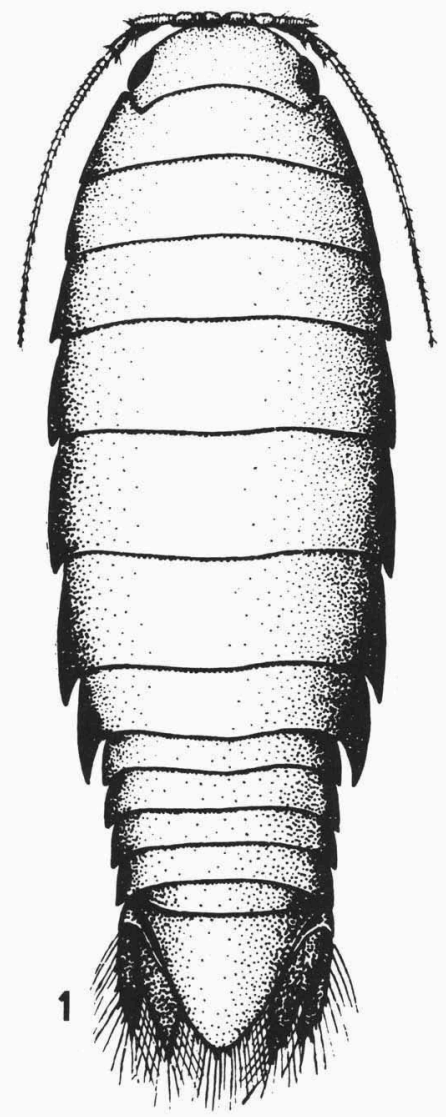

Fig. 1. Cirolana borealis, Q, $40 \mathrm{~mm}$ (after Gruner, 1965).

man North Sea coasts; the species should be rather common at depths of 20 meters and more.

Family CyмотноidaE Leach, 1814

Anilocra frontalis H. Milne Edwards, 1840

Anilocra physodes; Holthuis, 1972: 21, pl. 1

Anilocra frontalis; Trilles, 1977: 12. Huwae, 1977: 16, figs. 24, B 25. Holthuis, 1978: 28, fig. 1a.

The first record of this fish parasite in the Netherlands has been reported by Holthuis (1972, as $A$. physodes; 1978 , as $A$. frontalis). It concerned a female, collected on a specimen of the black sea bream, Spondyliosoma cantharus (Linnaeus, 1758), caught at $53^{\circ} 33^{\prime} \mathrm{N} 04^{\circ} 22^{\prime} \mathrm{E}$ (RMNH 3128). Trilles (1977) identified this specimen as $A$. frontalis $\mathrm{H}$. Milne Edwards, 1840 (see also Huwae, 1977). 


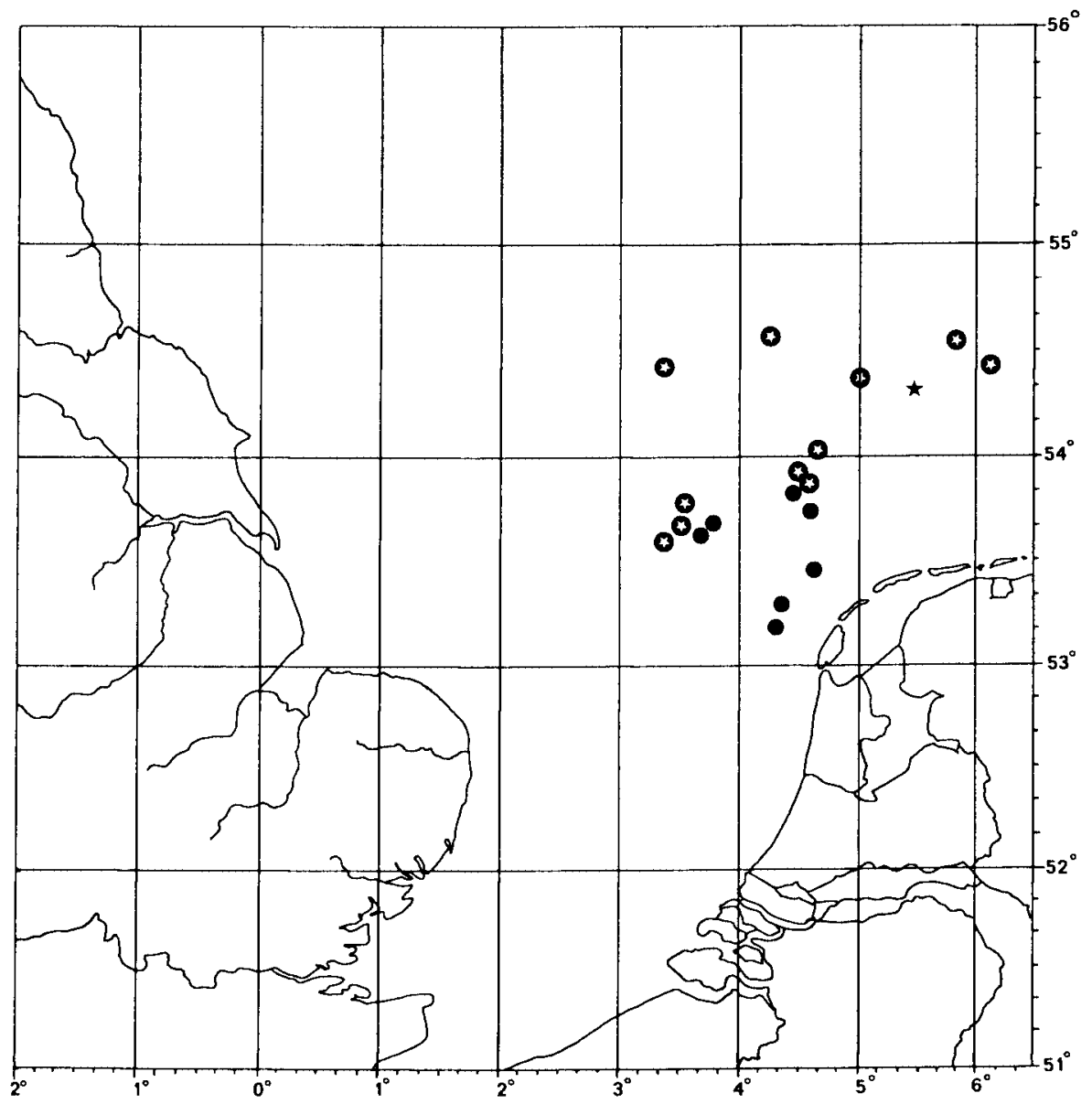

Map 2. Cirolana borealis in the southern North Sea; asterisk, specimen from the stomach of Raja batis; dots, specimens caught by RIVO and NIOZ; white asterisks, specimens from the stomaches of $M e r-$ langius merlangius

Nerocila maculata $H$. Milne Edwards, 1840

Nerocila maculata; Trilles, 1977: 13. Huwae, 1977: 16, figs. 23, B 24. Holthuis, 1978: 29, pl. 1.

Until now three specimens of this fish parasite were collected in the Netherlands; all three were found on specimens of the thick-lipped mullet, Crenimugil labrosus (Risso, 1826); one on 22.ix.1975 in the Mokbaai, at the southern part of the Island of Texel (RMNH 5141, leg. NIOZ), one on 23.iv.1976 at 't Horntje, at the south-eastern part of the Island of Texel (RMNH 5141 bis, leg. NIOZ) and the third one in May 1977 also at 't Horntje (RMNH 5631, leg. NIOZ). The first two were indentified by Dr. J. P. Trilles 
TABLE 2

Distribution of Cirolana borealis in the southern North Sea

$\begin{array}{llllll}\text { Date } & \text { Position } & \text { Sta. } & \text { Number } & \text { Leg. } & \text { Col. } \\ 26.1 .1950 & 54^{\circ} 18^{\prime} \mathrm{N} 05^{\circ} 21^{\prime} \mathrm{E} & - & 1 & \text { NIOZ* } & \text { RMNH } 3126 \\ \text { x.1954 } & 53^{\circ} 10^{\prime} \mathrm{N} 04^{\circ} 15^{\prime} \mathrm{E} & - & 1 & \text { P. Smit } & \text { RMNH } 1985 \\ 1 . \mathrm{vii} .1971 & 53^{\circ} 49^{\prime} \mathrm{N} 04^{\circ} 22^{\prime} \mathrm{E} & - & 3 & \text { M. Fonds } & \text { RMNH } 5715 \\ 1 . \mathrm{vii} .1971 & 53^{\circ} 44^{\prime} \mathrm{N} 04^{\circ} 27^{\prime} \mathrm{E} & - & 2 & \text { M. Fonds } & \text { RMNH } 5716 \\ 17 . x .1972 & 53^{\circ} 13^{\prime} \mathrm{N} 04^{\circ} 17^{\prime} \mathrm{E} & 180 & 2 & \text { NIOZ } & \text { RMNH } 6078 \\ 18 . \times i .1974 & 53^{\circ} 40^{\prime} \mathrm{N} 03^{\circ} 40^{\prime} \mathrm{E} & 326 & 6 & \text { NIOZ } & \text { RMNH } 5718 \\ 1 . x .1975 & 53^{\circ} 27^{\prime} \mathrm{N} 04^{\circ} 27^{\prime} \mathrm{E} & - & - & \text { RIVO } & - \\ 6 . x .1975 & 53^{\circ} 37^{\prime} \mathrm{N} 03^{\circ} 35^{\prime} \mathrm{E} & 345 & 3 & \text { NIOZ } & \text { RMNH } 5717\end{array}$

*: until 1960 the NIOZ was called "Zoologisch Station, Den Helder".

(Trilles, 1977; Holthuis, 1978), the last one by Dr. L. B. Holthuis (Holthuis, 1978). These form the first records of this species for the entire North Sea (Huwae, 1977; Holthuis, 1978).

Family Sphaeromatidae Latreille, 1815

Cymodoce truncata Leach, 1814

Cymodoce truncata; Spaink, 1962: 67. Holthuis, 1975: 65, fig. 1. Huwae, 1977: 14, fig. B 19.

One female of this species was found on 1.i.1962 on a glass fishing float, washed ashore on the beach at Oranjezon, on the north coast of the Island of Walcheren, province of Zeeland (Spaink, 1962). Until now this is the only record of this species for the Netherlands. It is very likely that the glass fishing float came from the Channel area (Holthuis, 1975).

Family IDOTEIDAe Samouelle, 1819

Idotea emarginata (Fabricius, 1793)

Idotea emarginata; Naylor, 1955: 257. Holthuis, 1956: 87, fig. 26. Van der Baan \& Holthuis, 1969: 360, table 4. Huwae, 1977: 13, figs. 14, B 10.

Holthuis (1956) cited a number of records of Idotea emarginata (Fabricius) of which the identification certainly is correct. In all cases these records concerned specimens which were washed ashore by means of floating objects like cork fishing floats, egg cases of the common whelk, Buccinum undatum Linnaeus, 1758 and thong-weed, Himantalia elongata (Linnaeus) Gray.

In the period 1961-1966, 30 specimens were collected in the surface plankton near the lightship "Texel" at $53^{\circ} 01^{\prime} 30^{\prime \prime} \mathrm{N} 04^{\circ} 22^{\prime} \mathrm{E}$; it is remarkable that 29 of these specimens were caught between 8 and 22.viii.1963 (Van der Baan \& Holthuis, 1969). 
On 28.vii. 1979 the authors found many thousands of isopods amongst a mass of washed ashore seaweeds (Enteromorpha spec., Fucus vesiculosus Linnaeus and Sargassum muticum (Yendo) Fensholt) on the beach between Katwijk and Noordwijk, province of Zuid-Holland. The greater part of these isopods could be identified as Idotea balthica (Pallas, 1772), a species common in the Netherlands, but several hundreds of specimens of $I$. emarginata were also found. Besides many juveniles there were also males with a length up to $34 \mathrm{~mm}$ and females, many of which ovigerous, with a length up to $22 \mathrm{~mm}$. Several specimens were collected and placed in the collection of the Leiden Museum (RMNH 5938).

Naylor (1955) mentioned loose masses of decaying seaweed as one of the substrates on which $I$. emarginata lives and from which it also feeds. The simultaneous presence of many hundreds of specimens of this species washed ashore on the Dutch coast, makes it likely that I. emarginata lives autochthonous in the southern North Sea off the Dutch coast.

Two other records of this species were received by the Central Register of the Strandwerkgemeenschap van de KNNV, NJN \& ACJN: one specimen was found on 11.vii.1979 on the beach of Huisduinen near Den Helder (leg. A. Roos-Huigen) and two specimens were found on 25.vii.1979 between Katwijk and Noordwijk (RMNH 5939, leg. W. J. Kuijper). These specimens obviously belong to the same invasion as those of RMNH 5938 dealt with above.

Idotea metallica Bosc, 1801-1802

(fig. 2)

Idotea metallica; Van der Baan \&olthuis, 1969: 358, table iv. Huysman \&uwae, 1978: 121, 1 fig.

Between 1961 and 196617 specimens of Idotea metallica Bosc were collected in the surface plankton near the lightship "Texel" at $53^{\circ} 01^{\prime} 30^{\prime \prime} \mathrm{N} 04^{\circ} 22^{\prime} \mathrm{E}$. These records were the first of this species for the southern North Sea (Van der Baan \& Holthuis, 1969).

One specimen of $I$. metallica was found on 7.vii.1978 on the beach near Bloemendaal, province of Noord-Holland (Huysman \& Huwae, 1978; RMNH 1153); another specimen was found on 11.viii.1979 on the beach between Katwijk and Noordwijk, province of Zuid-Holland, between clusters of hydroids washed ashore (RMNH 5933, leg. W. F. Prud'homme van Reine \& W. J. Kuijper). It seems likely that the species lives autochthonous in the southern North Sea.

I. metallica is often found among floating seaweed; the species is known from the eastcoast of North America, Japan, South Africa, the Mediterranean, the Azores, the westcoast of Great-Britain, the Netherlands and the westcoast of Greenland.

Family JaNiRIDae Sars, 1897

Jaera albifrons group

Jaera albifrons group; Forsman, 1949: 449, figs. 1-8. Bocquet, 1950: 132, figs. a-c. Holthuis, 1956: 104, fig. 34. Prud'homme van Reine-De Jager, 1966: 1, figs. 1-2. Naylor \& Haathela, 1966: 


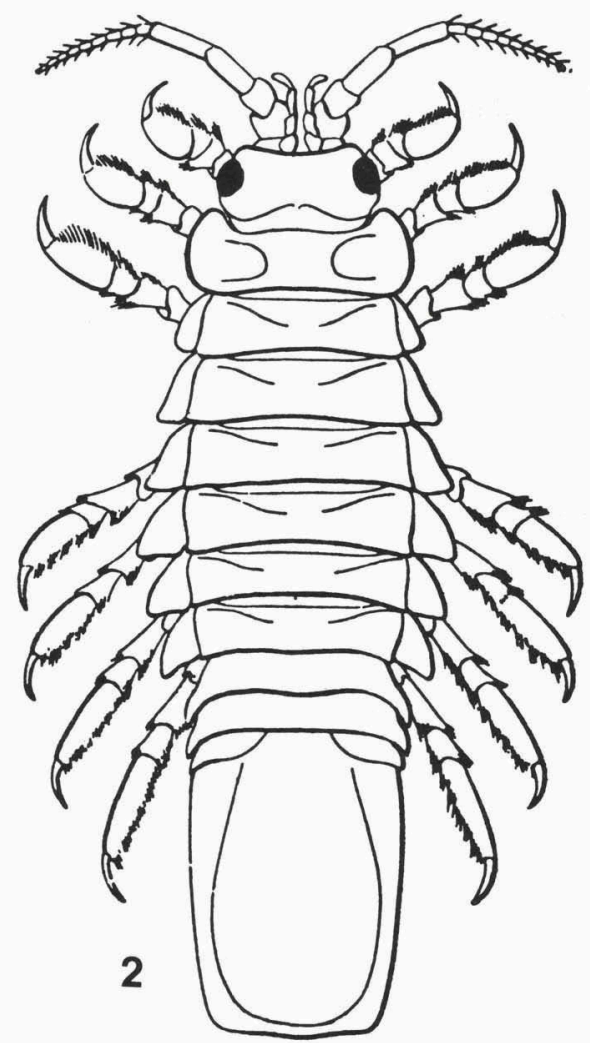

Fig. 2. Idotea metallica, $20 \mathrm{~mm}$ (after Richardson, 1905).

209, figs. 1, 2, tables i, ii. Harvey \& Naylor, 1967: 185, figs. 1-5, tables i-iv. Huwae, 1975 : 8 , figs. $1-6$; 1977 : 19 , figs. 35,36 , B 39-41.

Forsman (1949) and Bocquet (1950) revised the species Jaera albifrons Leach, 1815 and divided it in six taxa, based on characters of the sixth and seventh periopod of the male. Holthuis (1956) did not follow this classification and mentioned only $J$. albifrons s.l. Prud'homme van Reine-De Jager (1966) revised the collections of this species of the Leiden and Amsterdam Museums and come to the conclusion that two of the six taxa recognized by Forsman (1949) and Bocquet (1950) occurred in the Netherlands, viz. J. albifrons ischiosetosa Forsman, 1949 and $J$. albifrons syei Bocquet, 1950. Naylor \& Haathela (1966) raised five of the six taxa to the status of species; Harvey \& Naylor (1967) came to the conclusion that $J$. albifrons syei was not a subspecies but a form of $J$. albifrons. Both $J$. albifrons forma albifrons and $J$. albifrons forma syei occur in the Netherlands (Huwae, 1975, 1977). Of the species $J$. ischiosetosa, J. posthirsuta Forsman, 1949, $J$. praehirsuta Forsman, 1949 and J. forsmanni Bocquet, 1950, only J. ischiosetosa is found in the Netherlands (Prud'homme van Reine-De Jager, 1966; Huwae, 
$1975,1977)$. This species seems to be more euryhaline than J. albifrons forma albifrons and $J$. albifrons forma syei and is often found in brackish inland waters (Huwae, 1975, 1977). Taking into consideration the geographic and ecological distribution of the various other species of the genus, only $J$. praehirsuta can also be expected to be found in the Netherlands.

Family Arcturidae Dana, 1852

Astacilla longicornis (Sowerby, 1806)

(fig. 3; table 3)

Astacilla longicornis; G. O. Sars, 1899: 88, pl. 36. Nierstrasz \&chuurmans Stekhoven, 1930: Xe 94, fig. 11. Holthuis, 1950: 13, fig. 5. Gruner, 1965: 89, figs. 71-76. Naylor, 1972: 49, fig. $14 d$.

During the "Aurelia" cruises of the NIOZ eight specimens of Astacilla longicornis (Sowerby) were collected; seven from the English part of the southern North

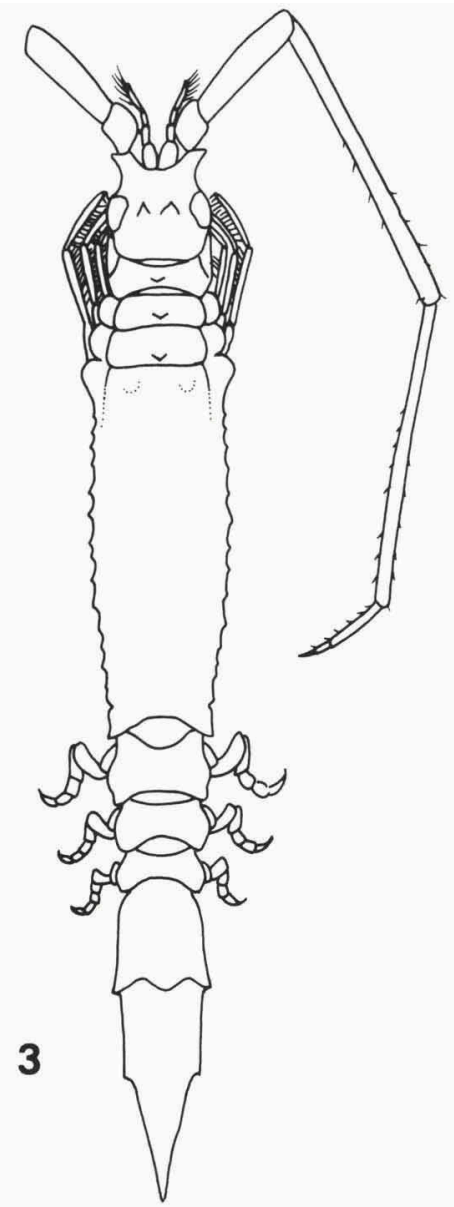

Fig. 3.Astacilla longicornis, $\$, 30 \mathrm{~mm}$ (after Sars, 1899). 
Sea off Newcastle, one between the Wadden Islands Texel and Vlieland (Sta. 311 , table 3). The latter proved to be the first record of this species for the Netherlands. According to Gruner (1965) A. longicornis inhabits the entire North Sea. Records are known from the British coast (Naylor, 1972), the Danish coast (Nierstrasz \& Schuurmans Stekhoven, 1930; Gruner, 1965), Helgoland (Gruner, 1965), and the southernmost part of the North Sea (Holthuis, 1950). The specimens quoted by Holthuis all were collected in the years 1903-1911.

In view of its distribution the occurrence of this species in the Netherlands was to be expected. Therefore it is surprising that $A$. longicornis was not included by Holthuis (1956) and Huwae (1977) in their enumeration of the Dutch Isopoda.

TABLE 3

Distribution of Astacilla longicornis in the southern North Sea

$\begin{array}{lllll}\text { Date } & \text { Position } & \text { Sta. } & \text { Number } & \text { Col. } \\ 16 . x .1974 & 55^{\circ} 21^{\prime} \mathrm{N} 00^{\circ} 21^{\prime} \mathrm{W} & 302 & 1 \mathrm{fem} . & \text { NIOZ } \\ 16 . \times 1974 & 55^{\circ} 11^{\prime} \mathrm{N} 00^{\circ} 10^{\prime} \mathrm{W} & 303 & 1 \mathrm{fem} . & \text { RMNH } 6044 \\ 16 . \times 1974 & 54^{\circ} 57.5^{\prime} \mathrm{N} 00^{\circ} 05^{\prime} \mathrm{W} & 304 & 1 \mathrm{fem} . & \text { RMNH } 6046 \\ 17 . \times .1974 & 55^{\circ} 19^{\prime} \mathrm{N} 00^{\circ} 42^{\prime} \mathrm{E} & 306 & 2 \mathrm{fem} . & \text { RMNH } 6045 \\ & & & 2 \mathrm{mal} . & \\ 18 . \times .1974 & 53^{\circ} 16^{\prime} \mathrm{N} 04^{\circ} 5 \mathrm{I}^{\prime} \mathrm{E} & 311 & 1 \mathrm{fem} . & \text { RMNH } 6047\end{array}$

Arcturella dilatata (G. O. Sars, 1882)

(fig. 4)

Arcturella dilatata; G. O. Sars, 1899: 92, pl. 34. Nierstrasz \& Schuurmans Stekhoven, 1930: Xe 98, fig. 45. Holthuis, 1950: 13. Naylor, 1972: 49.

The "Aurelia" obtained one female of Arcturella dilatata (G. O. Sars), collected on $17 . x .1974$ at $55^{\circ} 19^{\prime} \mathrm{N} 00^{\circ} 42^{\prime} \mathrm{E}$ (Sta. 306). Females of this species are easily recognized by the striking pair of spines on the middle pereional somite (fig. 4). In the North Sea $A$. dilatata is known from the Skagerrak, the Kattegat, the southwest coast of Norway, Great Britain (Nierstrasz \& Schuurmans Stekhoven, 1930) and from the Galloper Bank (Holthuis, 1950). Naylor (1972) gives for the English littoral the record of one specimen from the Isle of Man.

The "Aurelia" specimen was the first of this species to form part of the RMNH collection (RMNH 6010).

Family Bopyridae Rafinesque, 1815

All Bopyrid isopods are parasites on Decapoda, living either in the branchial cavity or attached to the abdomen. Representatives of this family always show a clear sexual dimorphism: the very small, symmetrical male lives (parasitically) on the abdomen of the much larger, asymmetrical female.

The first record for the Netherlands of Pseudione hyndmanni (Bate \& Westwood, 1868) (Huwae, 1978) induced the senior author to search a sample of 820 


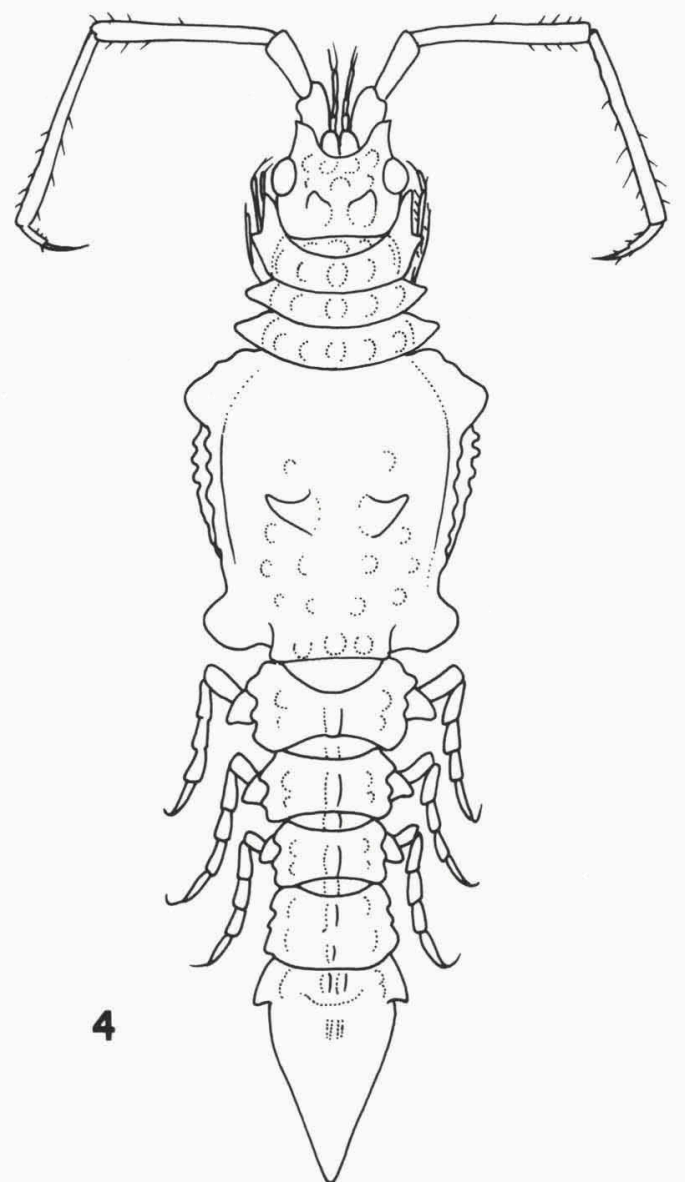

Fig. 4. Arcturella dilatata, ९, $6 \mathrm{~mm}$ (after Sars, 1899).

specimens of the hermit crab Pagurus bernhardus (Linnaeus, 1758) for parasites. The hermit crabs were collected in the southern North Sea during the "Aurelia" cruises of the NIOZ (1972-1979). The results of an examination of 220 specimens of $P$. bernhardus have been described separately (Adema, 1980), and are incorporated here. Except for one specimen of P. hyndmanni (Sta. E. 85), which is in the NIOZ collection, all hosts and parasites were placed in the RMNH collection.

Besides P. hyndmanni and Athelges paguri (Rathke, 1843), P. berhardus is also infected by the rhizocephalan Peltogaster paguri Rathke, 1843, of which 21 specimens were found. Because of the risk that otherwise these interesting data might be overlooked, and because the hyperparasitic isopod Liriopsis pygmaea 
(Rathke, 1843) was found on a specimen of $P$. paguri, the data on this rhizocephalan are incorporated in this paper.

The classification of subfamilies of the Bopyridae according to Codreanu (1967) is used here.

Subfamily Athelginae M. \& R. Codreanu, 1956

Athelges paguri (Rathke, 1843)

(table 4; map 3)

Athelges paguri; Holthuis, 1950: 14; 1956: 234, fig. 80a-c. Bourdon, 1960: 11; 1963: 423. Naylor, 1972: 70, fig. 23d. Huwae, 1977: 11, fig. B 5. Adema, 1980: 32, figs. 2a-c.

Athelges paguri (Rathke) lives dorsally attached to the soft abdomen of the hermit crab Pagurus bernhardus (Linnaeus, 1758). The distribution of this species in the southern North Sea is poorly known, although the fact that its host is very common in this area. Naylor (1792) included and figured the species, but gave no exact data. Holthuis (1950) quoted only one specimen, collected in 1905 near the lightship "West-Hinder", between $51^{\circ} 21^{\prime} 30^{\prime \prime}$ à $51^{\circ} 19^{\prime} 30^{\prime \prime} \mathrm{N}$ and $02^{\circ} 29^{\prime} 30^{\prime \prime}$ à $02^{\circ} 25^{\prime} \mathrm{E}$. Until the examination of the 820 specimens of $P$. bernhardus mentioned above, the Leiden Museum held only two specimens of this species from the southern North Sea: one collected on 10.xii.1900 in the Oostgat near the Island of Walcheren (RMNH 894, ex. coll. J. G. De Man) (Holthuis, 1956; Huwae, 1977), the other collected on 18.vii.1957 along the west side of the Texel Stones, a stony area west of the Island of Texel (RMNH 1940).

Ten out of 820 specimens of $P$. bernhardus $(1.2 \%)$ proved to be parasitized by A. paguri (table 4, map 3) (see also Adema, 1980). Bourdon $(1960,1963)$ found the following percentages of infestation in two localities in Brittany, France: Quiberon, $1.0 \%$ and Roscoff, $1.1 \%$.

Besides the specimens from the southern North Sea, the RMNH collection holds one other specimen of this species, collected 20.viii.1974 near Treath Bycham, Anglesey, Wales $\left(53^{\circ} 30^{\prime} \mathrm{N} 04^{\circ} 14^{\prime} \mathrm{W}\right)$, on $P$. bernhardus from the lit-

TABLE 4

Distribution of Athelges paguri in the southern North Sea

\begin{tabular}{|c|c|c|c|c|}
\hline Date & Position & Sta. & Number & Col. \\
\hline 30.ix. 1975 & $54^{\circ} 30^{\prime} \mathrm{N} 03^{\circ} 10^{\prime} \mathrm{E}$ & 339 & 1 & RMNH 6071 \\
\hline $7 . x .1975$ & $54^{\circ} 28^{\prime} \mathrm{N} 02^{\circ} 24^{\prime} \mathrm{E}$ & 346 & 1 & RMNH 6067 \\
\hline $7 . x .1975$ & $54^{\circ} 23^{\prime} \mathrm{N} \quad 02^{\circ} 32^{\prime \prime} \mathrm{E}$ & 347 & 1 & RMNH 6066 \\
\hline $15 . x \cdot 1975$ & $52^{\circ} 49^{\prime} \mathrm{N} \quad 03^{\circ} 16^{\prime} \mathrm{E}$ & 363 & 1 & RMNH 6070 \\
\hline 12.xi. 1975 & $52^{\circ} 53^{\prime} \mathrm{N} 02^{\circ} 46^{\prime} \mathrm{E}$ & 389 & 2 & RMNH 6069 \\
\hline $12 . x i .1975$ & $53^{\circ} 07^{\prime} \mathrm{N} 03^{\circ} 26^{\prime} \mathrm{E}$ & 392 & 1 & RMNH 6072 \\
\hline 25.ii.1976 & $52^{\circ} 48^{\prime} \mathrm{NO} \quad 2^{\circ} 34^{\prime} \mathrm{E}$ & 411 & 1 & RMNH 6068 \\
\hline $17 . x .1977$ & $53^{\circ} 43^{\prime} \mathrm{N} 04^{\circ} 14^{\prime} \mathrm{E}$ & E 85 & 1 & RMNH 6065 \\
\hline-- & "North Sea" & - & 1 & RMNH 6073 \\
\hline
\end{tabular}




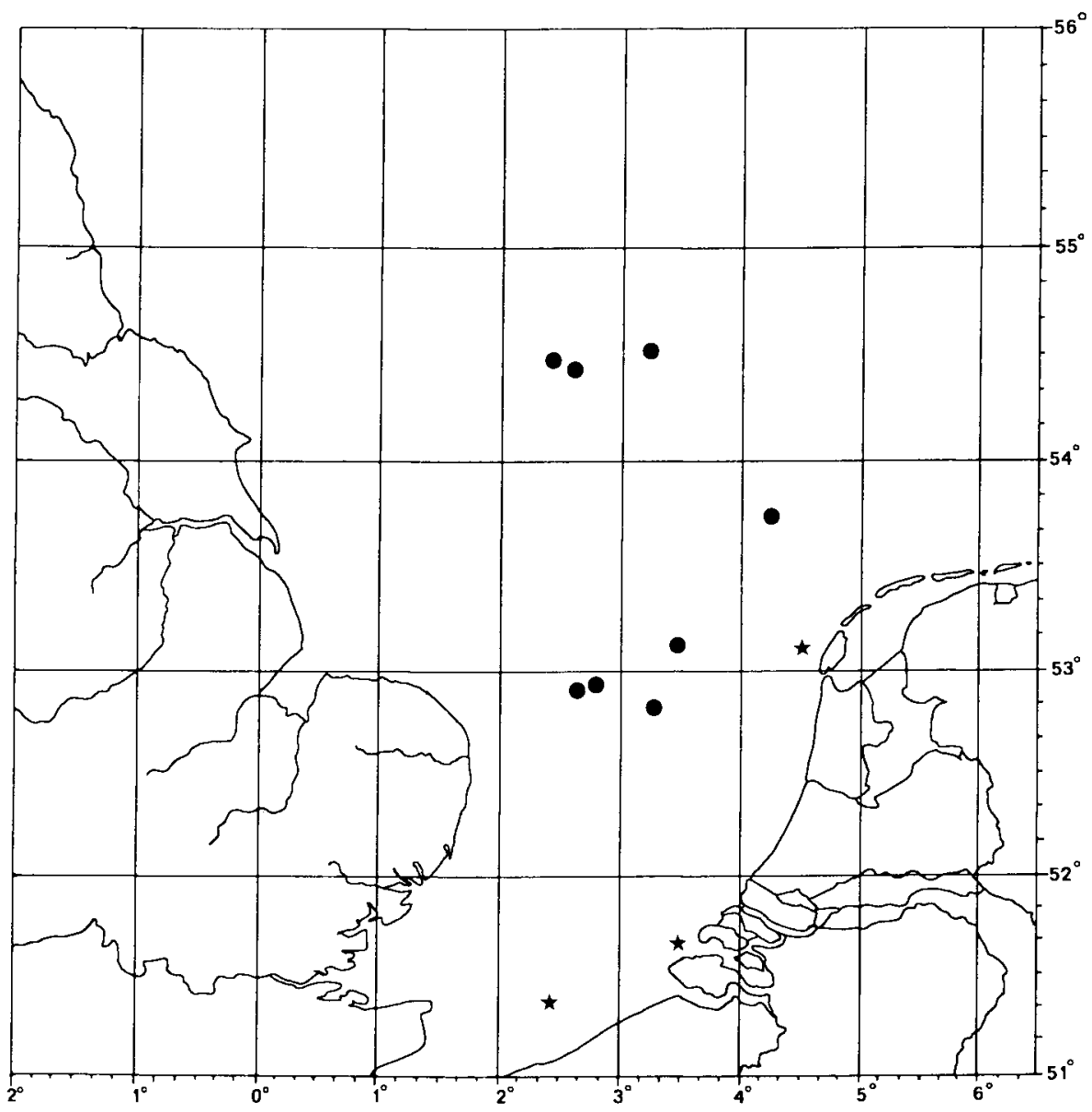

Map 3. Athelges paguri in the souther North Sea: dots, records from the "Aurelia"'-cruises; asterisks, other records.

toral. The same specimen of the hermitcrab was also parasitized by Pseudione hyndmanni.

Subfamily Ioninae Dana, 1852

Ione thoracica (Montagu, 1808)

(fig. 5)

Ione thoracica; Holthuis, 1950: 15.

Four females of Ione thoracica were found in bottomsamples, taken in the southern North Sea during the "Aurelia" cruises. The specimens were collected from samples taken on 11.v. 1981 at $53^{\circ} 39.5^{\prime} \mathrm{N} 04^{\circ} 21^{\prime} \mathrm{E}$ (1 ex.), on 13.vii. 1981 at $53^{\circ} 50.4^{\prime} \mathrm{N} 05^{\circ} 10.2^{\prime} \mathrm{E}\left(1 \mathrm{ex}\right.$.) and also on 13. vii.1981 at $53^{\circ} 35.5^{\prime} \mathrm{N}$ 


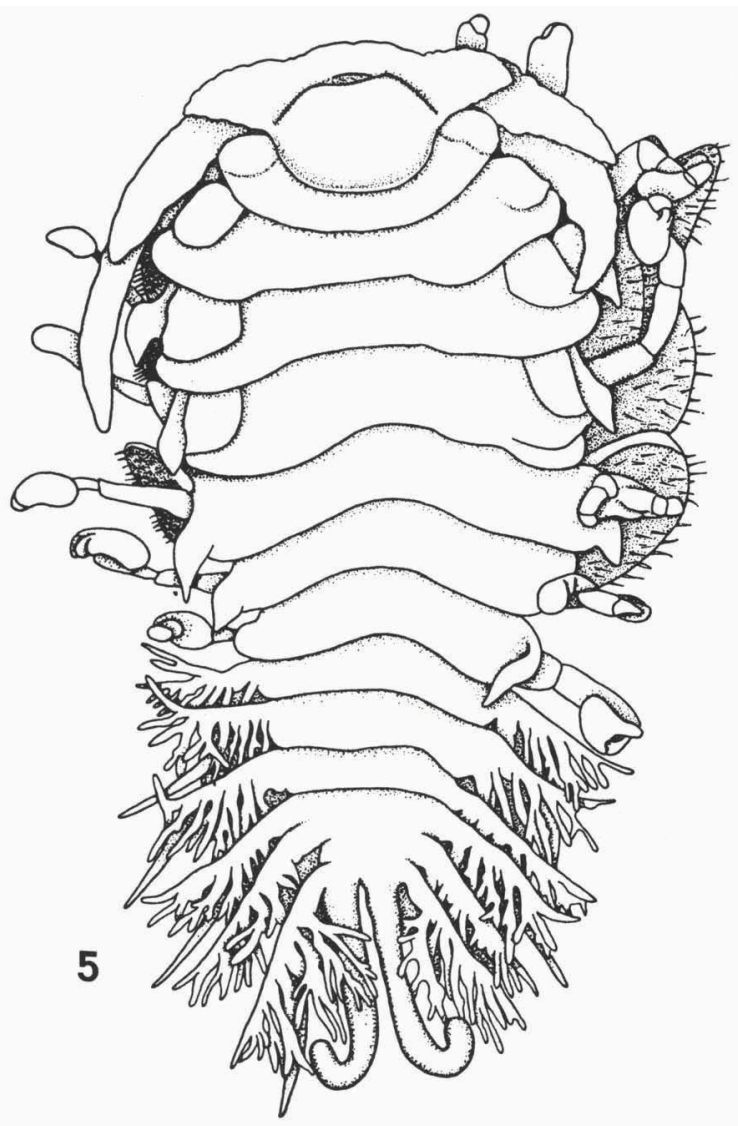

Fig. 5. Ione thoracica, \&, $8 \mathrm{~mm}$ (after Bourdon, 1968).

$04^{\circ} 14.5^{\prime} \mathrm{E}(2 \mathrm{ex}$.$) . This species is a parasite of the burrowing lobsters Callianassa$ tyrrhena (Petagna, 1792) and C. subterranea (Montagu, 1808). In the bottomsamples there were no specimens of the hosts, but during the days mentioned above, several specimens of $C$. subterranea were collected. $I$. thoracica has not been reported before from the Netherlands. One time it has been found off the Belgian coast: in 1899 one specimen was collected on a specimen of $C$. subterranea caught at $51^{\circ} 15^{\prime} \mathrm{N} 02^{\circ} 54^{\prime} \mathrm{E}$ (Holthuis, 1950). The specimens from the Netherlands form now part of the RMNH-collection, but are not yet registered.

Subfamily Pseudioninae Codreanu, 1967

Pleurocrypta porcellanea Hesse, 1876 (fig. 6a-c)

Pleurocrypıa porcellanae; Nierstrasz \& Brender à Brandis, 1926: Xe 25, figs. 60, 61. Bourdon, 1968: 281, figs. 113-121, tables 45-50, graphs 18-21. Naylor, 1972: 74. Huwae, 1976: 65, figs. 1-3, map 1; 1977: 11, fig. B 3a, b. 

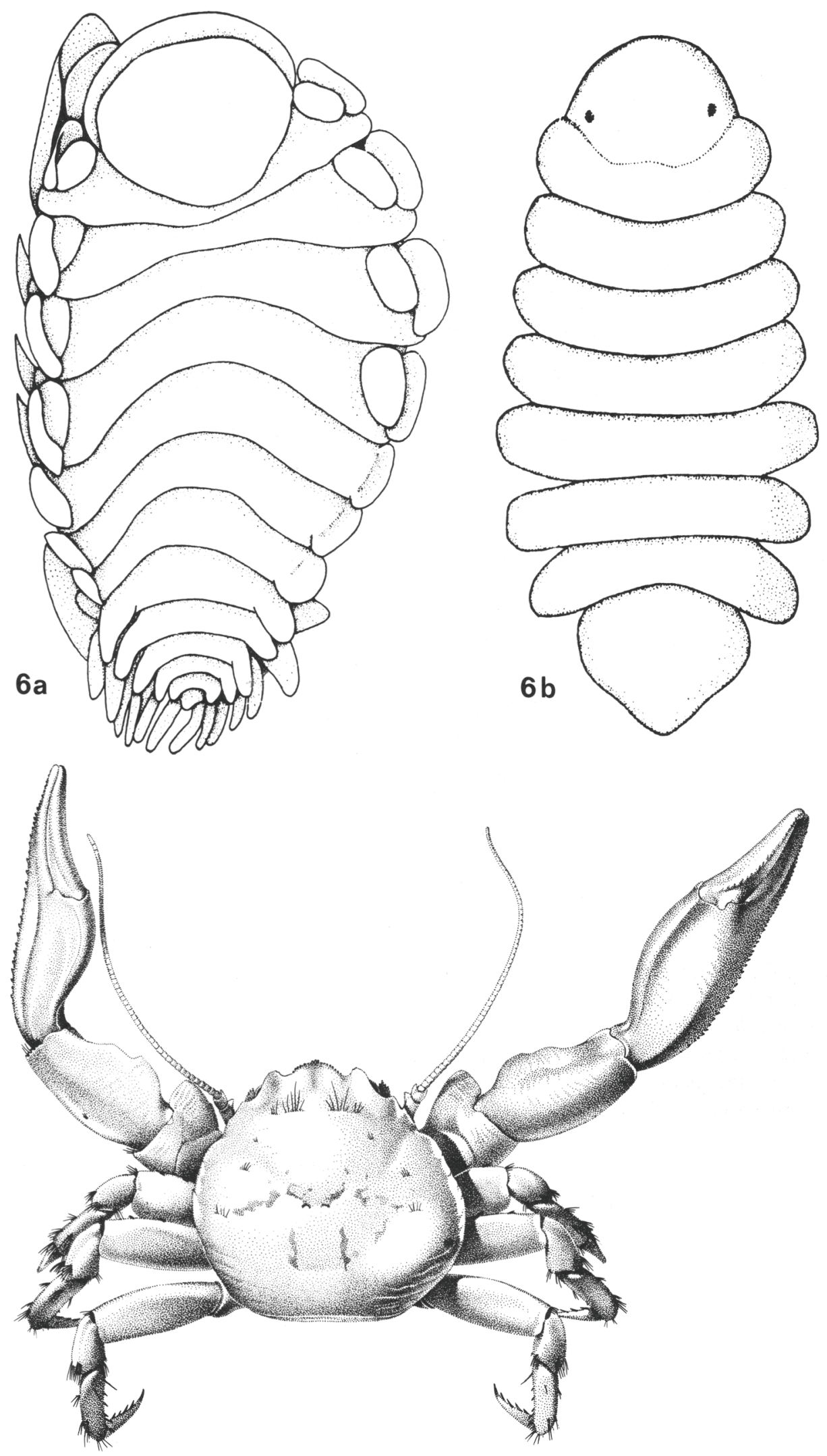
A single pair of Pleurocrypta porcellanae Hesse (female carrying a male) was found when 100 specimens of Pisidia longicornis (Linnaeus, 1758), caught near the Brown Ridge, were examined for parasites. The parasitized specimen of $P$. longicornis was easily recognized by the swollen branchial cavity, in which the parasite lives (fig. 6c) (RMNH 4508; Huwae, 1976, 1977). In the southern North Sea the species has been reported from the east coast of Great Britain near Newcastle (Huwae, 1976) and the Cullercoats District (Naylor, 1972). Furthermore it was reported from the Channel near Wimereux, N. W. France (Nierstrasz \& Brender à Brandis, 1926; Huwae, 1976).

\section{Pseudione hyndmanni (Bate \& Westwood, 1868)}

(fig. 7a-b; table 5; map 4)

Pseudione hyndmanni: Bonnier, 1900: 295, pl. 18. Nierstrasz \& Brender à Brandis, 1926 Xe 21, figs. 24-39. Bourdon, 1960: 12; 1963: 426: 1968: 144, figs. 60-72, graph 8. Naylor, 1972: 75, fig. 230-q. Huwae, 1979: 71, fig. 1a, b. Adema, 1980: 32, fig. 1a, b.

Pseudione proxima Bonnier, 1900: 298. Nierstrasz \& Brender à Brandis, 1926: Xe 20, figs. 34-39, 43, 44. Holthuis, 1950: 14 .

Little is known of the distribution of Pseudione hyndmanni (Bate \& Westwood) in the southern North Sea. Nierstrasz \& Brender à Brandis (1926, as P. proxima and $P$. hyndmanni) gave no records of this species from this area. Naylor (1972) mentioned and figured this species for the British coasts, but gave no exact data and localities. Holthuis (1950, as $P$. proxima) quoted four localities in the southernmost part of the North Sea, where the species had been found. From the Netherlands one specimen is known, collected on a specimen of Pagurus bernhardus (Linnaeus, 1758) from the beach at Katwijk, province of Zuid-Holland on 27.v.1979 (RMNH 5929; Huwae, 1979). Until then the collection of the RMNH held only two other specimens from the southern North Sea: one collected 40 miles north-west of IJmuiden, between 21 and 24.vi.1955 (RMNH 1988, leg. A. v. d. Houwen), the other collected between 6 and 10.xi.1969 at the Texel Stones (RMNH 3131, leg. unknown) (map 4).

Thirty-seven out of 820 examined hermit crabs were found to be infested by $P$. hyndmanni $(4.4 \%)$ (table 5; map 4); Bourdon $(1060,1963)$ found an infestation of $0.1 \%$ at Quiberon and of $0.5 \%$ at Roscoff.

One of the examined specimens of $P$. bernhardus had a specimen of $P$. hyndman$n i$ in either branchial cavity (Sta. 389); another was parasitized by both $P$. hyndmanni and Peltogaster paguri Rathke, 1843 (Sta. 412).

Besides these specimens from the North Sea, The RMNH collection holds two more specimens, both collected on 20.viii.1974 near Treath Bycham, Anglesey, Wales $\left(53^{\circ} 20^{\prime} \mathrm{N} 04^{\circ} 14^{\prime} \mathrm{W}\right)$, on two specimens of $P$. bernhardus. One of these hermit crabs also carried a specimen of Athelges paguri (RMNH 6139).

Fig. 6a, b. Pleurocrypta porcellanae (ater Bourdon, 1968). a, Q, $4.6 \mathrm{~mm}$; b, ơ , $0.8 \mathrm{~mm}$. Fig. 6c. Pisidia longicornis, infested specimen, $20 \mathrm{~mm}$ (W. C. G. Gertenaar, RMNH, del) 


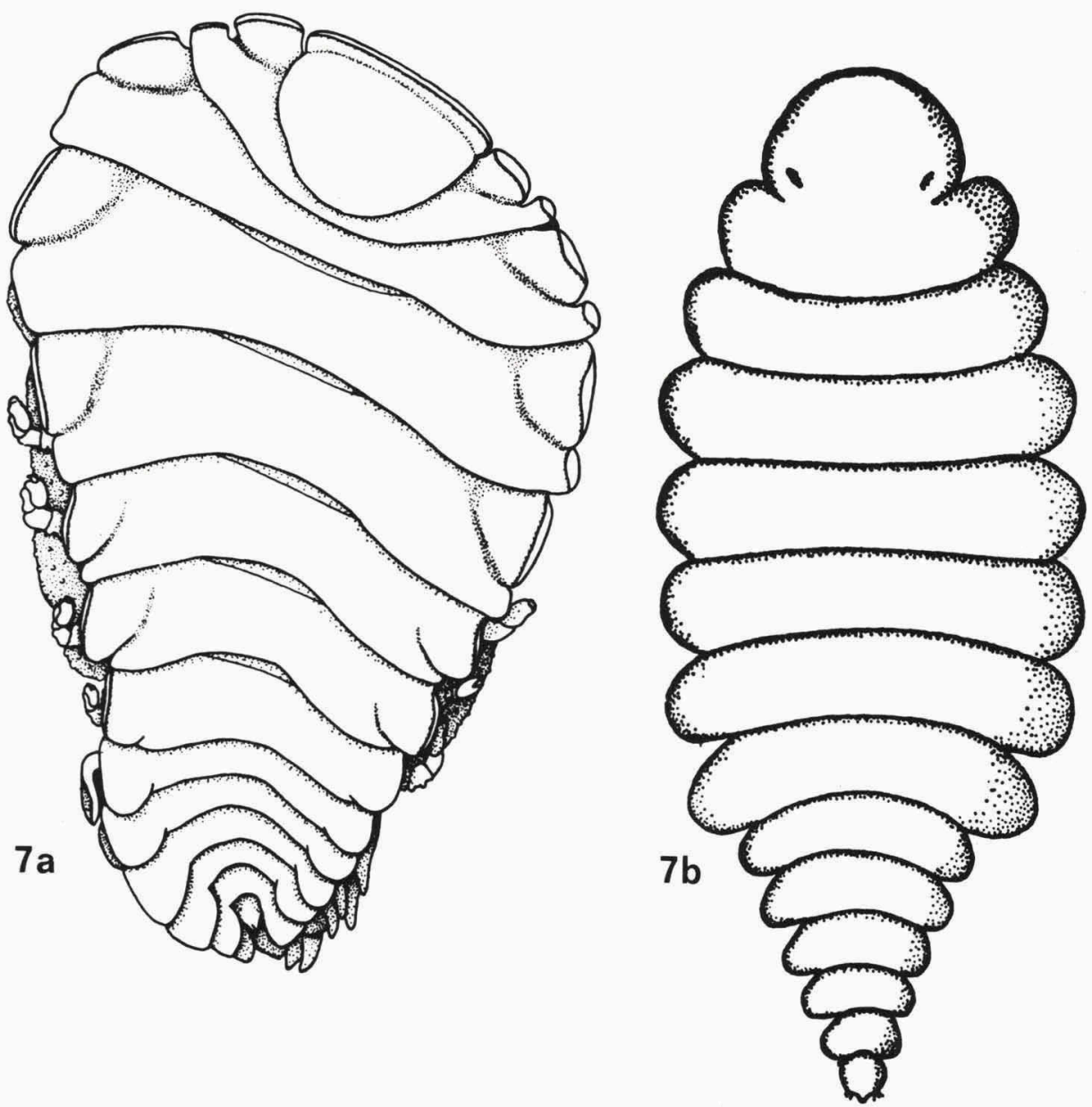

Fig. 7a, b. Pseudione hyndmanni (after Bourdon, 1968). a, $\$, 7 \mathrm{~mm}$; b, o , $2 \mathrm{~mm}$.

Bonnier (1900) described $P$. proxima as a species different from $P$. hyndmanni Bourdon (1968) did not regard them as distinct taxa, which opinion is followed here.

\section{Family LiRIOPTIDAE}

\section{Liriopsis pygmaea (Rathke, 1843)}

$$
\text { (fig. 8a-b) }
$$

Liriope pygmaea Rathke, 1843: 60, pl. 1 figs. 8-12.

Liriopsis pygmaea; G. O. Sars, 1899: 242, pl. 99 fig. 3, pl. 100 fig. 1. Nierstrasz Brender à Brandis, 1926: Xe 14, figs. 9-17. Bourdon, 1963: 422. Naylkor, 1972: 78. 
TABLE 5

Distribution of Pseudione hyndmanni in the southern North Sea

\begin{tabular}{|c|c|c|c|c|}
\hline Date & Position & Sta. & Number & Col. \\
\hline $17 . x \cdot 1974$ & $55^{\circ} 26^{\prime} \mathrm{N} \quad 00^{\circ} 29^{\prime} \mathrm{E}$ & 305 & 1 & -- \\
\hline $17 . x .1974$ & $55^{\circ} 19^{\prime} \mathrm{N} \quad 00^{\circ} 42^{\prime} \mathrm{E}$ & 306 & 3 & -- \\
\hline $30 . i x .1975$ & $54^{\circ} 29^{\prime} \mathrm{E} 03^{\circ} 33^{\prime} \mathrm{E}$ & 337 & 1 & - \\
\hline $30 . i x .1975$ & $54^{\circ} 19^{\prime} \mathrm{N} \quad 03^{\circ} 24^{\prime} \mathrm{E}$ & 338 & 1 & -- \\
\hline $30 . i x .1975$ & $54^{\circ} 30^{\prime} \mathrm{N} 02^{\circ} 56^{\prime} \mathrm{E}$ & 340 & 1 & -- \\
\hline $7 . x .1975$ & $54^{\circ} 28^{\prime} \mathrm{N} \mathrm{O} 2^{\circ} 24^{\prime} \mathrm{E}$ & 346 & 1 & -- \\
\hline $11 . x i .1975$ & $52^{\circ} 33^{\prime} \mathrm{N} 03^{\circ} 07^{\prime} \mathrm{E}$ & 383 & 1 & -- \\
\hline $11 . x i .1975$ & $52^{\circ} 24^{\prime} \mathrm{N} 02^{\circ} 45^{\prime} \mathrm{E}$ & 385 & 2 & -- \\
\hline 25.ii. 1976 & $52^{\circ} 48^{\prime} \mathrm{N} \quad 02^{\circ} 34^{\prime} \mathrm{E}$ & 411 & 1 & - \\
\hline 25.ii.1976 & $52^{\circ} 41^{\prime} \mathrm{N} \quad 02^{\circ} 38^{\prime} \mathrm{E}$ & 412 & 1 & - \\
\hline 25.ii. 1976 & $52^{\circ} 33^{\prime} \mathrm{N} 02^{\circ} 43^{\prime} \mathrm{E}$ & 413 & 1 & -- \\
\hline $25 . i i .1976$ & $52^{\circ} 24^{\prime} \mathrm{N} 02^{\circ} 47^{\prime} \mathrm{E}$ & 414 & 2 & -- \\
\hline 25.ii. 1976 & $52^{\circ} 35^{\prime} \mathrm{N} \quad 03^{\circ} 12^{\prime} \mathrm{E}$ & 416 & 2 & -- \\
\hline $24 . i .1980$ & $52^{\circ} 49^{\prime} \mathrm{N} \quad 04^{\circ} 25.5^{\prime} \mathrm{E}$ & $\mathrm{Ha} 2$ & 1 & - \\
\hline
\end{tabular}

One female of Liriopsis pygmaea (Rathke, 1843) was found on a specimen of Peltogaster paguri Rathke, 1843, collected on 17.x.1974 at $55^{\circ} 19^{\prime} 00^{\circ} 42^{\prime} \mathrm{E}$ (Sta $306)$. It appeared to be the first one in the RMNH collection (RMNH 6014).

The species is a protandrous hermafrodite. The male, being the last larval stage (fig. 8a) lives either free or in the body cavity of $P$. paguri (Rathke, 1843; Sars, 1899); it attains a length of $1.3 \mathrm{~mm}$. The female (fig. 8b) lives attached to the body of $P$. paguri; it attains a length of $5 \mathrm{~mm}$. Rathke (1843) did not know the female, but described the species on eight males, found in the body cavity of $P$. paguri.

In the North Sea the species has been recorded from Denmark (Nierstrasz \& Brender à Brandis, 1926) and from Great Britain (Naylor, 1972). Neither Nierstrasz \& Brender à Brandis nor Naylor gave exact locality data. Bourdon (1963) found two specimens of $L$. pygmaea on nine specimens of $P$. paguri at Roscoff.

Order Rhizocephala

Family Peltogastridae Lilljeborg

Peltogaster paguri Rathke, 1843

(table 6; map 5)

Peltogaster paguri; Boschma, 1961: 24, fig. 34. Bourdon, 1960: 3; 1963: 416. Adema, 1980: 32 fig. 3. 


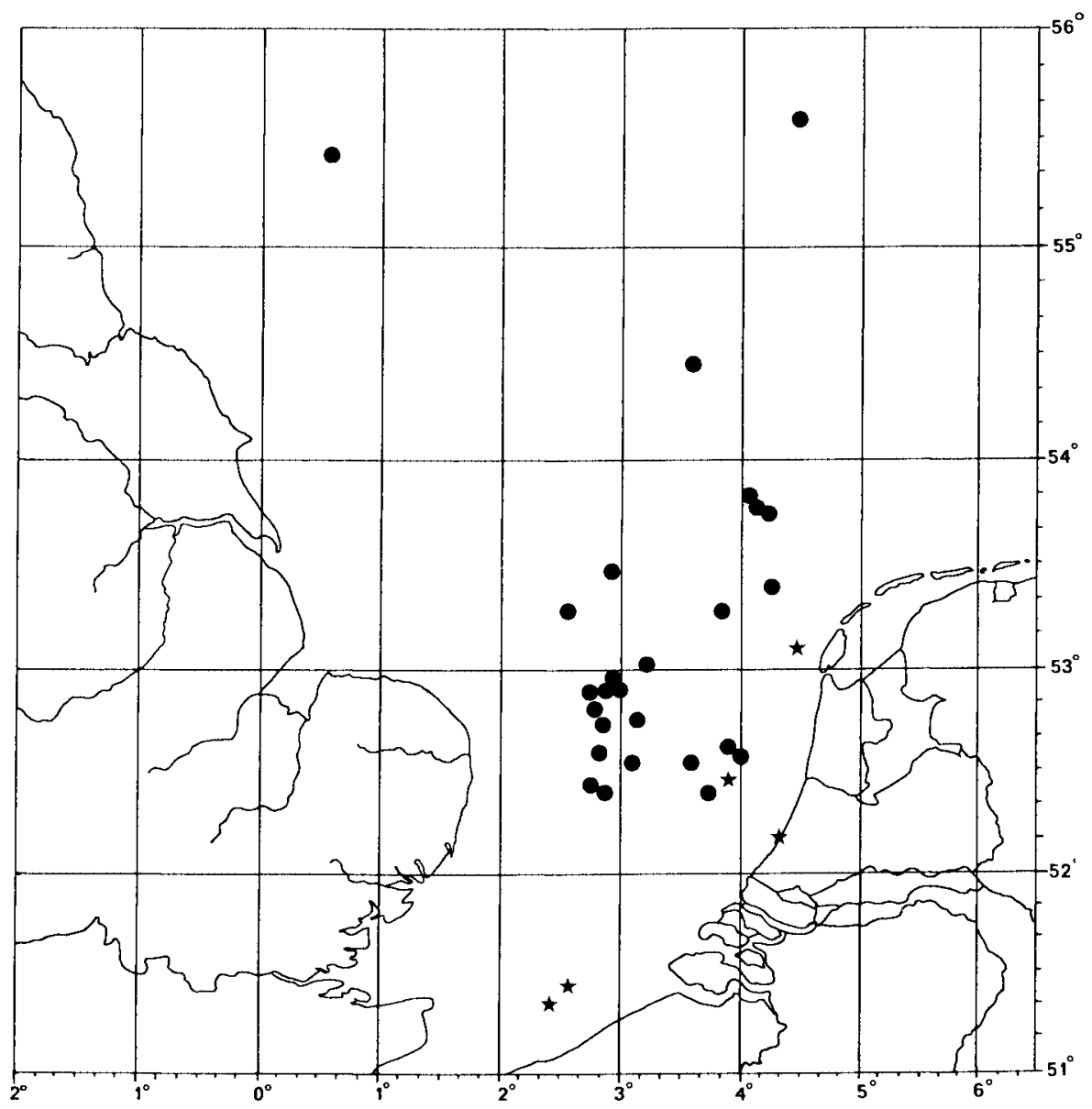

Map 4. Pseudione hyndmanni in the southern North Sea: dots, records from the "Aurelia"-cruises; asterisks, other records.

Data on Peltogaster paguri Rathke, living on the soft abdomen of Pagurus bernhardus (Linnaeus, 1758) and other species of Pagurus are rather scarce. According to Boschma (1961) the species is very rare in the North Sea.

On 820 specimens of $P$. bernhardus from the southern North Sea 21 specimens of $P$. paguri were found (2.4\%) (table 6, map 5). One of the hermit crabs was infested by two specimens of the Rhizocephalan (Sta. 414). At Quiberon $1.4 \%$ of the hermit crabs were infested (Bourdon, 1960), at Roscoff $0.3 \%$ (Bourdon, 1963).

The RMNH collection holds four other specimens of $P$. paguri from the southern North Sea: one specimen collected on 28.x.1949 at Katwijk, province of Zuid-Holland (RMNH 1080, leg. J. A. W. Lucas), two specimens collected on 1.xi.1949 at Scheveningen, province of Zuid-Holland (RMNH 186, 1081, 

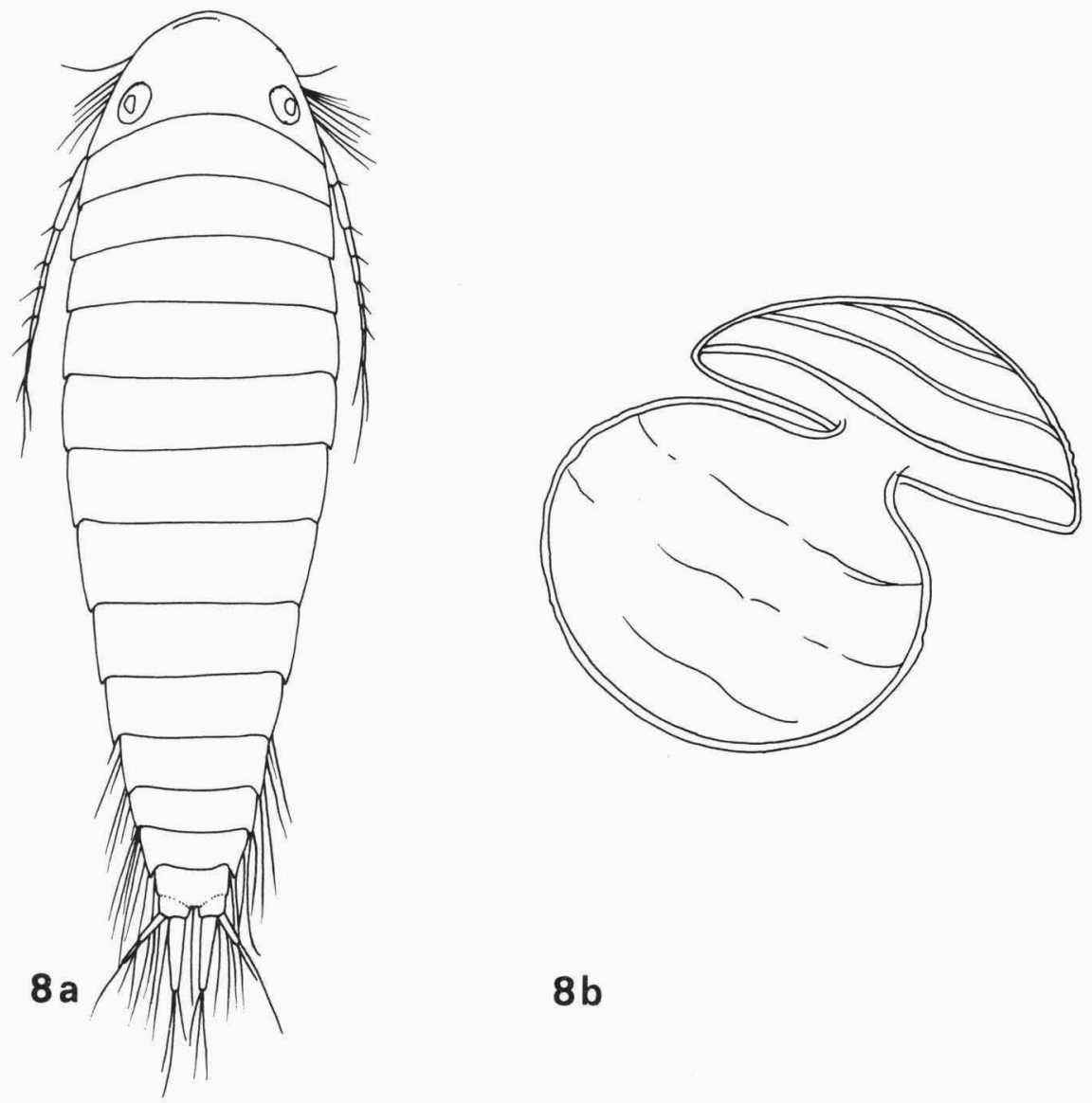

Fig. 8a, b. Liriopsis pygmaea (after Sars, 1899). a, ơ, $1.3 \mathrm{~mm}$; b, ९, $5 \mathrm{~mm}$.

leg. J. A. W. Lucas) and one specimen collected on 12.viii.1971 at $53^{\circ} 11^{\prime} \mathrm{N}$ $04^{\circ} 15^{\prime}$ E (RMNH 1299, leg. G. R. Heerebout).

Besides these specimens from the North Sea the collection of the Leiden Museum holds one other specimen of $P$. paguri collected on 20.viii.1974 near Treath Bycham, Anglesey, Wales.

\section{AcKNowledGements}

The authors wish to thank Dr. F. Creutzberg and G. J. van Noort, NIOZ, Texel, for providing the material collected during the "Aurelia"-cruises, Mrs. R. H. Borghouts-Biersteker, Miss E. Alkema, Mr. R. Lambeck and Mr. J. Goosen, Delta Instituut, Yerseke, for providing the data concerning the distribution of Cyathura carinata, Mr. A. Fortuin, also Delta Instituut, for drawing our attention to the fact that $C$. carinata still occurs in the Delta area, Miss C. 
TABLE 6

Distribution of Peltogaster paguri in the southern North Sea

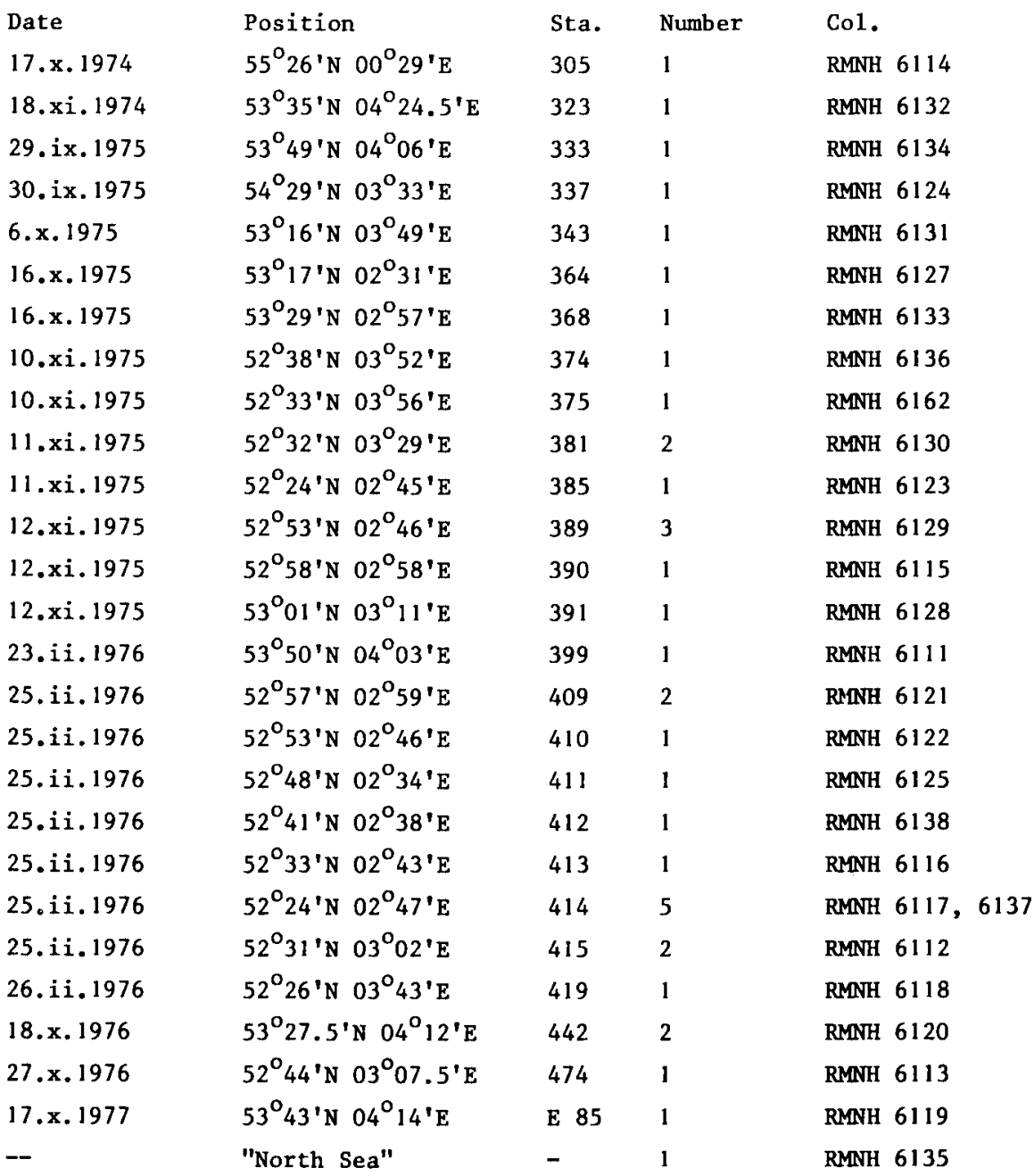

Winkelman, NIOZ, Texel, for the data concerning the specimens of Cirolana borealis, from the stomachs of the whiting, Mr. T. J. J. de Boo, Leiden, for his assistance with the English translation and Dr. L. B. Holthuis, Rijksmuseum van Natuurlijke Historie, Leiden, for much advice and critically reading the manuscript. 


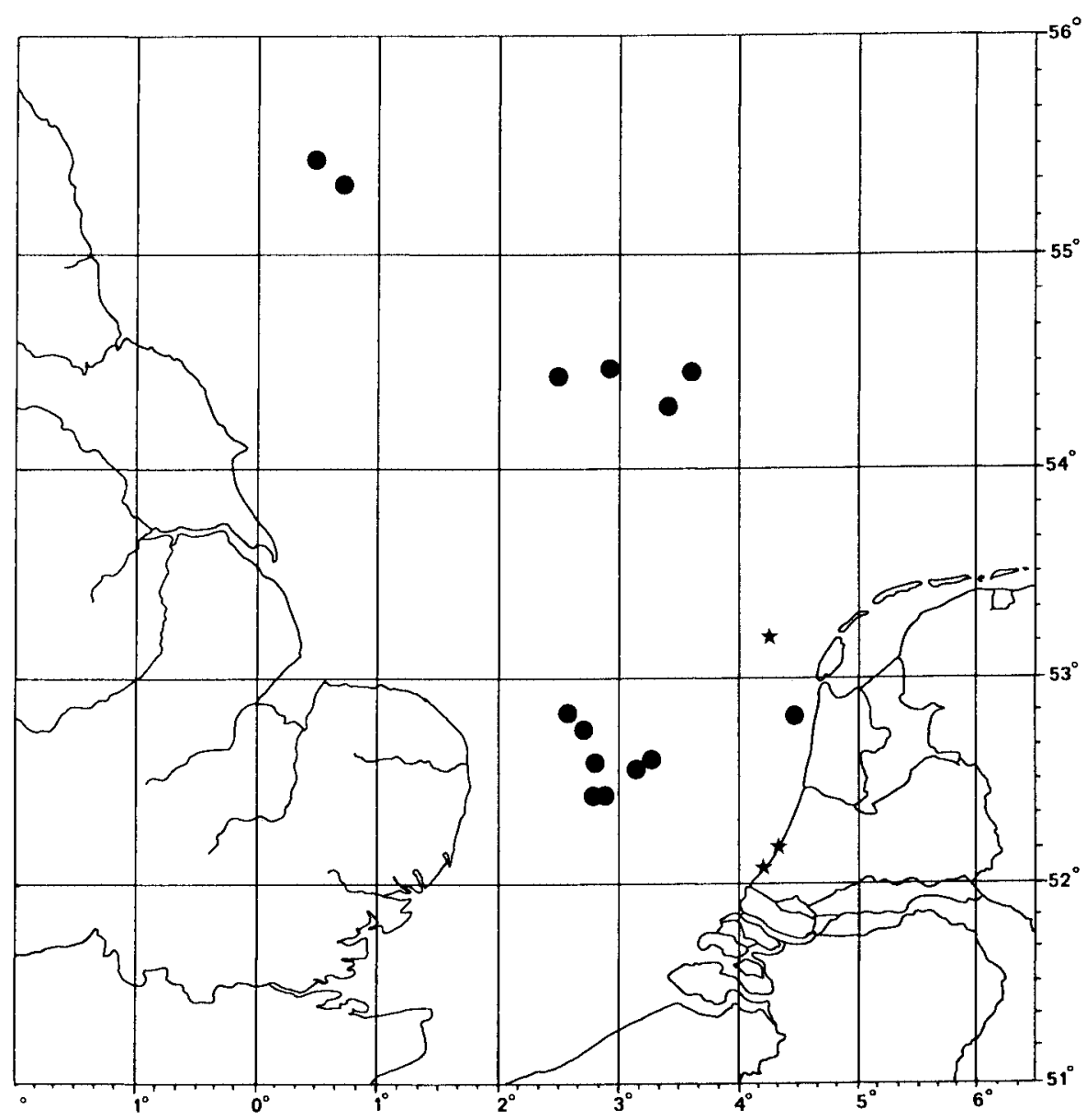

Map 5. Peltogaster paguri in the southern North Sea: dots, records from the "Aurelia"-cruises; asterisks, other records.

\section{SAmenVAtTing}

Sinds het verschijnen van deel 16 van de Fauna van Nederland, Isopoda \& Tanaidacea (Holthuis, 1956), zijn van de door Holthuis genoemde soorten mariene Isopoda veel nieuwe gegevens bekend geworden; tevens werden 13 soorten nieuw voor Nederland en de zuidelijke Noordzee gevonden. In dit artikel wordt een samenvatting gegeven van de vondsten van de nieuwe en enkele interessante, reeds uit ons land bekende, soorten.

Een onderzoek aan 820 exemplaren van de heremietkreeft Pagurus bernhardus (Linnaeus, 1758), verzameld in de zuidelijke Noordzee, tijdens de "Aurelia"'-cruises van het NIOZ (Creutzberg, 1979), leverde een groot aantal gegevens op over de twee soorten parasitaire isopoden die van deze heremietkreeft bekend zijn. Behalve de pissebedden werden op $P$. bernhardus ook vele exemplaren gevonden van het krabbezakje Peltogaster paguri Rathke, 1843. Om te voorkomen dat deze interessante gegevens in de vergetelheid zouden geraken, werd besloten om $P$. paguri in dit artikel op te nemen. 
Twee van de behandelde soorten, Liriopsis pygmaea (Rathke, 1843) en Arcturella dilatata (G. O. Sars, 1882), waren nog niet in de collectie van het Rijksmuseum van Natuurlijke Historie vertegenwoordigd; het materiaal van deze soorten was eveneens afkomstig van de "Aurelia"'-cruises.

\section{REFERENCES}

Adema, J. P. H. M., 1980. De heremietkreeft (Pagurus bernhardus (Linné, 1758)) en haar parasieten. - Het Zeepaard, 40 (2): 32-35, figs. 1-3, table 1.

BAAN, S. M. VAN DER \& L. B. Holthuis, 1969. On the occurrence of Isopoda in the surface plankton near the lightship "Texel". - Neth. J. Sea Res., 4 (3): 354-363, tables i-v.

Bocquet, C., 1950. Le problème taxonomique des Jaera marina Fabr. (J. albifrons Leach). C. r. hebd. Séanc. Acad. Sci, Paris, 230: 132-134, figs. A-C.

Bonnier, J., 1900. Contribution à l'étude des épicarides. Les Bopyridae. - Trav. Sta. zool. Wimereux, 8: 1-475, figs. 1-62, pls. 1-61.

Boschma, H., 1961. Orde Rhizocephala (krabbezakjes). In: H. Boschma, F. de GraAf, L. B. Holthuis \& J. A. W. Lucas. Rankpotigen (Cirripedia). - S. W. G. tabellenserie, 19: 22-26, figs. 30-37.

Bourdon, R., 1960. Rhizocephales et isopodes parasites des décapodes marcheurs de la Baie de Quiberon. - Bull. Soc. Sc. Nancy, (n.s.) 19 (2-3): 134-153.

- , 1963. Epicarides et Rhizocéphales de Roscoff. - Cah. Biol. mar., 4 (4): 415-434.

- - 1968. Les Bopyridae des mers Européennes. - Mém. Mus. Hist. Nat. Paris, (n. ser. A, Zool.) 50 (2): 77-424, figs. 1-190, tables 1-68, graphs. 1-30.

Burbanck, W. D. \& M. P. Burbanck, 1964. A comparison of dorsal patterns of the estuarine isopods Cyathura polita of North America and C. carinata of Europe. - Verh. Internat. Verein. Limnol., 15: 865-870, figs. 1-6.

Codreanu, R., 1967. Clasificarea evolutivà a bopirienilor, isopode parazite ale crustaceelor decapode şi importąnta lor biologică generalaă. - Studii Cerc. Biol., 19 (3): 203-211.

Creutzberc, F., 1979. "Aurelia"'-cruise reports on the benthic fauna of the southern North Sea. Introductory report. - Interne Verslagen Nederlands Instituut voor Onderzoek voor Onderzoek der Zee, Texel, 1979-4: 1-31, maps. 1-13.

Forsman, B., 1949. Weitere Studien über die Rassen von Jaera albifrons Leach. - Zool. Bidr. Upps., 27: 449-463, figs. 1-8.

Gruner, H.-E., 1965. Krebstiere oder Crustacea. V. Isopoda I. - Tierwelt Dtl., 51 : I-VII, 1-149, figs. $1-119$.

HARTOG, C. DEN, 1961. Die faunistische Gliederung im Südwest-niederländischen Deltagebiet. Int. Revue Ges. Hydrobiol., 46 (3): 407-418, figs. 1-5.

Harvey, C. E. \& E. Naylor, 1967. The taxonomic status of Jaera albifrons syei Bocquet (Isopoda Asellota). - Crustaceana, 14: 185-193, figs. 1-5, tables I-II.

Holthuis, L. B., 1950. Isopodes et Tanaidacés marins de la Belgique; remarques sur quelques espèces de la zone méridionale de la Mer du Nord. - Bull. Inst. Roy. Sci. nat. Belg., 26 (53): 1-19, 6 figs.

- , 1954. XIV. Crustacea Isopoda. In: L. F. DE BEAufort (ed.). Veranderingen in de Flora en Fauna van de Zuiderzee (thans IJsselmeer) na de afsluiting in 1932: 205-212.

--, 1956. Isopoda en Tanaidacea (KV). In: H. Boschma (ed.), Fauna Ned., XVI: 1-280, figs. 1-89.

- - 1972. De isopode Anilocra physodes (Linnaeus, 1758) voor de Nederlandse kust gevonden. Zool. Bijdr., Leiden, 13: 21-23, 1 plate.

- - 1975. De mariene isopode Cymodoce truncata Leach, 1814, in Nederland gevonden. Zool. Bijdr., Leiden, 17: 65-67, fig. 1.

- - 1978. Cymothoide isopoden van de Nederlandse kust en de zuidelijke Noordzee. Zool. Bijdr., Leiden, 23: 28-33, fig. 1a, b, pl. 1.

Huysman, M. \&. H. M. Huwae, 1978. De eerste vondst van Idotea metallica Bosc 18011802 (Crustacea Isopoda) aan de Nederlandse kust. - Het Zeepaard, 38 (5/6): 121-122, 1 fig. 
Huwae, P. H. M., 1975. Over de Nederlandse vertegenwoordigers van het pissebeddengeslacht Jaera. - Het Zeepaard, 35 (1): 8-12, figs. 1-6.

- - 1976. Waarnemingen van Pleurocrypta porcellanae Hesse en Cirolana borealis (Lilljeborg) (Crustacea, Isopoda) voor de Nederlandse kust. - Het Zeepaard, 36 (4): 65-70, figs. 1-3, map 1 .

- - 1977. De Isopoden van de Nederlandse kust. - Wet. Meded. K. Ned. natuurh. Veren., 118: 1-144, figs. 1-38, B 1-149.

- - 1979. De eerste melding van Pseudione hyndmanni (Bate \& Westwood, 1868). - Crustacea, Isopoda, Epicaridea - voor Nederland. - Het Zeepaard, 39 (4): 71-73, fig. 1.

NAYLOR, E., 1955. The ecological distribution of British species of Idotea (Isopoda). J. anim. Ecol., 24: 255-269, figs. 1-4.

-_, 1972. British Marine Isopods. - Synopsis Br. Fauna (new series), 3: 1-86, figs. 1-23.

Naylor, E. \& I. HaAthela, 1966. Habitat preferences and interspersion of species within the superspecies Jaera albifrons Leach (Crustacea, Isopoda). - J. anim. Ecol., 35: 209-216, figs. 1, 2, tables, I, II.

Nierstrasz, H. F. \& J. H. Schuurmans Stekhoven, 1930. Isopoda genuina. In: G. Grimpe \& E. Wagler (eds.), Tierwelt N. u. Ostsee, 10 (e2): 57-133, figs. 1-85.

Nierstrasz, H. F. \& G. A. Brender à Brandis, 1926. Isopoda Epicaridea. In: G. Grimpe \&. Wagler (eds.), Tierwelt N. u. Ostsee, 10 (e1): 2-56, figs. 1+171,

Prud'homme van Reine-De Jager, H., 1966. The distribution of the subspecies of Jaera albifrons Leach (Crustacea, Isopoda, Asellota), in the Netherlands. - Beaufortia, 14 (164): 1-4, figs. $1,2$.

Rathke, H., 1843. Beiträge zur Fauna Norwegens. I, Crustacea. - N. Acta Acad. Leop. Carol., 20: 1-132, pls. 1-6.

Richardson, H., 1905. A monograph on the Isopoda of North America. - Bull. U. S. natn. Mus., 54: VII-LIII, 1-727, figs. 1-740.

SARs, G. O., 1899 (1896-1899). An account of Crustacea of Norway. 2. Isopoda: 1-270, pls. 1-100, suppl. pls. I-IV.

Schuurmans Stekhoven, J. H., 1944. Isopoden van de Zuiderzee. - Biologie Zuiderzee tijdens Drooglegging, 6: 24-28.

Schuurmans Stekhoven, J. H. \& J. W. de Marees van Swinderen, 1936. Isopoda. In: H. C. REDEke (ed.), Flora en Fauna der Zuiderzee. Monografie van een brakwatergebied. Supplement: 119,120 .

Spaink, G., 1962. CS-feuilleton I. - Het Zeepaard, 22 (4): 63-69.

Trilles, J. P., 1977. Les Cymothoidea (Isopoda, Flabellifera; parasites des poissons) du Rijksmuseum van Natuurlijke Historie de Leiden. Méditerranée et Atlantique Nord-Oriental. - Zool. Meded., Leiden, 52 (2): 7-17.

Vos, A. P. C. DE, 1939. Over de Oever- en Bodemfauna der binnendijkse kolken langs de kust van het IJsselmeer. - Handel. Hydrobiol. Cl., 2: 1-9.

- - 1941. Zoologische resultaten van een tocht rond het IJsselmeer van 5-8 juli 1937 . Biologie Zuiderzee tijdens Drooglegging, 5: 37-50, 1 fig.

WolfF, W. J., 1966. Notes on Eurydice (Isopoda, Flabellifera) from the Netherlands. Zool. Meded., Leiden, 41 (14): 221-227, figs. 1-3.

,-- 1973 . The estuary as a habitat. An analysis of data on the softbottom macrofauna of the area of the rivers Rhine, Meuse and Scheldt. - Zool. Verh., Leiden, 126: 3-242, figs. 1-46, tables 1-11. 